Elsevier required licence: (C) <year>. This manuscript version is made available under the CC-BY-NC-ND 4.0 license http://creativecommons.org/licenses/by-nc-nd/4.0/

The definitive publisher version is available online at https://doi.org/10.1016/j.ecoser.2019.100988 
$\underline{\text { Title }}$

Engaging Absentee Landholders in Ecosystem Service Delivery in South-Eastern Australia

$\underline{\text { Author names and affiliations }}$

Hermann $\mathrm{Kam}^{1}$

Graciela Metternicht ${ }^{1}$

Alex Baumber $^{2}$

Rebecca Cross ${ }^{3}$

${ }^{1}$ School of Biological, Earth and Environmental Sciences, PANGEA Research Centre, UNSW Sydney, Australia

${ }^{2}$ Faculty of Transdisciplinary Innovation, University of Technology Sydney, Australia

${ }^{3}$ School of Life and Environmental Sciences and School of Geoscience, University of Sydney, Australia

\section{Corresponding author}

Hermann Kam

email address: hermann.kam@student.unsw.edu.au

postal address: School of BEES

The University of New South Wales

UNSW Sydney, NSW 2052

Australia

\section{Declaration of interest: None}

This research did not receive any specific grant from funding agencies in the public, commercial, or not-for-profit sectors. 


\title{
Engaging Absentee Landholders in Ecosystem Service Delivery in South-Eastern Australia
}

\author{
Hermann Kam, Graciela Metternicht, Alex Baumber, Rebecca Cross
}

\begin{abstract}
As absentee landownership continues to increase in many regions of Oceania and the world, there is a growing need to better understand the behaviours and values of this landholder group. The increase in absentee landholdership can impact the provision of ecosystem services, as well as alter the rural socio-cultural fabric; the values, beliefs, knowledge types and social connections amongst landholders in rural communities. Consequently, this presents challenges to natural resource management (NRM) practitioners seeking to implement better resource management strategies across property boundaries. This case study research on the Central Tablelands of New South Wales, Australia, aims to better understand the characteristics of absentee landholders, including their motivations for holding land, their existing levels of knowledge concerning land management practices, and their views and preferences for cross-property collaborations and, in turn, explore the role they could have in the delivery of ecosystem services.
\end{abstract}

Our results show that recreation and amenity relating to private cultural services are the main drivers of land acquisition and motivation for land use by absentee landholders in the region. Cross-property collaborations that absentee landholders are most interested in are related to the maintenance of supporting and regulating services, particularly through weed management and pest animal control. An important implication of these findings is that the facilitation of cross-property collaboration, by accommodating for a growing heterogeneity in values and beliefs, can become a mechanism for enhancing the delivery of public-benefit ecosystem services from absenteeheld land.

KEYWORDS: Absentee Landholder; Behaviours; Amenity absenteeism; Recreation; Lifestylers; Crossproperty collaborations

\section{Introduction}

Changing land use patterns have the potential to affect the delivery of ecosystem services by private landholders in the largest by area and the most developed country in Oceania, Australia (see Maynard et. al, this issue for more on the Oceania region). Many parts of rural Australia with high amenity values, and within a few hours' drive of large cities, have experienced a substantial rise in absentee landholdership and amenity migration in recent decades (Holmes, 2006; Morrison et al., 2015). The Central Tablelands region of New South Wales (NSW), west of Sydney, is a prime example of this trend, with large numbers of smallholdings held for lifestyle rather than production reasons (Merson et al., 2011; Central West Independent Review Panel, 2007). Similar increases in land being held by absentee landholders have also been observed in other parts of the world (Petrzelka and Armstrong, 2015; Ulrich-Schad et al., 2016), with implications for land management, conservation and the provision of ecosystem services across property boundaries.

Despite the upward trend in absentee landholdership, research to better understand the behaviour of absentee landholders in production and conservation landscapes have so far been scarce (Petrzelka and Armstrong, 2015). Possible reasons for the limited research on this 
theme are due to the lack of distinction made between owner-occupiers and absentee landholders in many studies (Bond et al., 2017), and the challenges associated with reaching absentee landholders through traditional social and institutional networks (Petrzelka and Armstrong 2015). The case study research this paper presents arose from a recent project on landholder collaboration in the Central Tablelands funded by the NSW Environmental Trust, where absentee landholders were identified as a key stakeholder group difficult to reach through traditional landholders' contact channels of face-to-face interviews and workshops (Baumber et al., 2018).

While absentee landholders are often overlooked in rural social research, they have the potential to make major contributions to the delivery of ecosystem services in regions where they hold significant quantities of land (Figure 1). Absentee landholders are often motivated to hold land due to the private lifestyle services it can provide in relation to amenity and recreation (Morrison et al., 2015). Conversely, their lower dependence on the land for income can reduce the provisioning services supplied by rural land in the affected region (Holmes, 2006). Furthermore, as ecological services rarely abide by human-imposed boundaries (Meadows et al., 2013), absentee landholders have the potential to influence supporting and regulating services related to biodiversity conservation, soil formation and water quality. The cross-property nature of these ecosystem services requires collaboration between neighbouring landholders (Rickenbach et al., 2011), especially given the fact that previous research into absentee landholders has highlighted the risks of negative outcomes for key ecosystem services in cases where they lack practical land management knowledge (Redmon et al., 2004; Buman, 2007; Petrzelka et al., 2013; Morrison et al., 2015). 


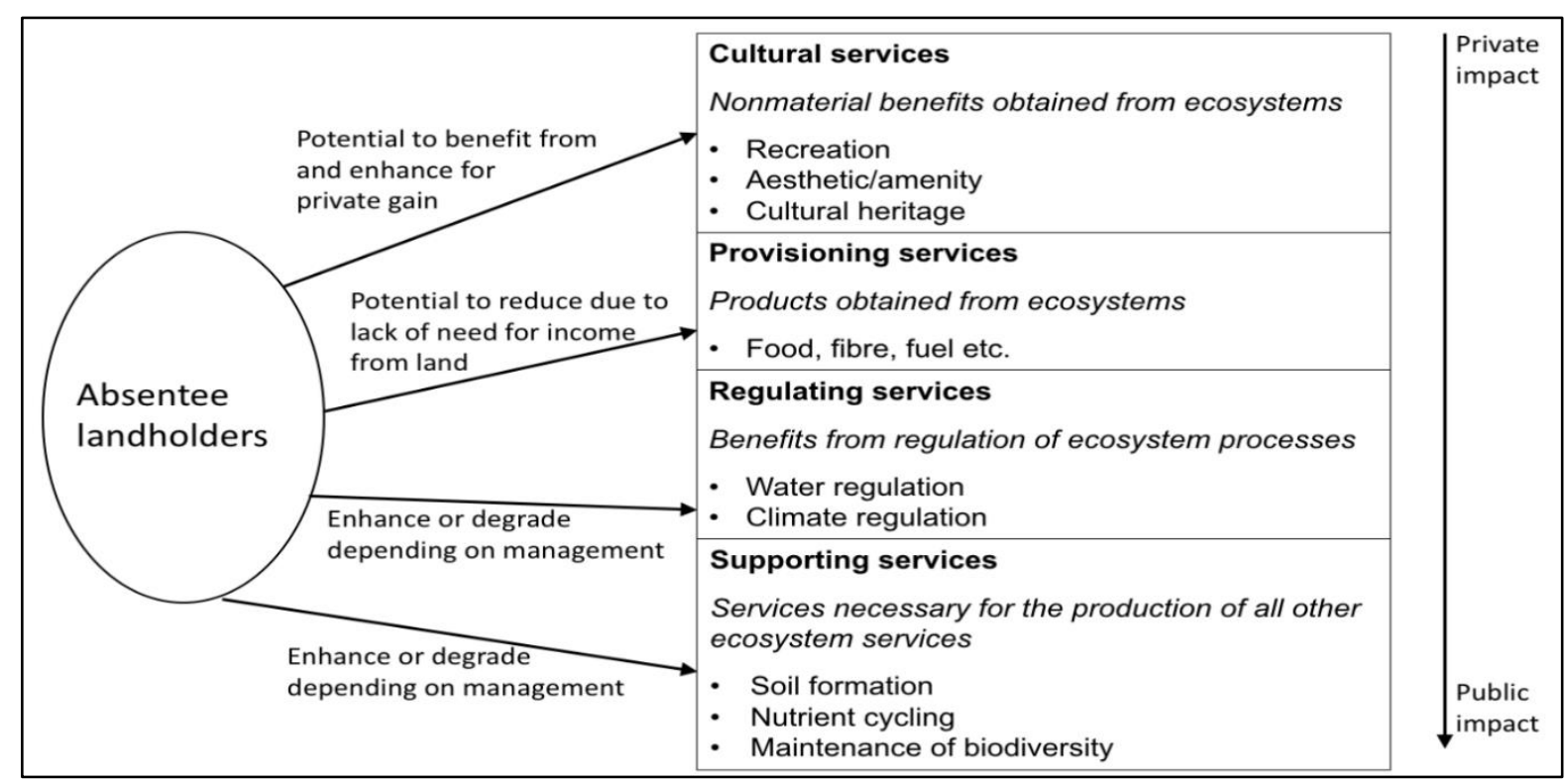

Figure 1. Potential impacts on absentee landholdership on ecosystem services. Categories and descriptions of ecosystem services from Millennium Ecosystem Assessment (2003).

With that in mind, the case study aims to gain a deeper insight into:

1) The purposes for which absentee landholders use their land;

2) Absentee landholders' levels of knowledge and experience in managing their land and the factors influencing it; and

3) The role that cross-property collaboration could play in ecosystem service delivery.

The remainder of section 1 profiles absentee landholders, including how the population rise has affected rural communities and the significance of cross-property collaborations. Section 2 entails the methodology of this research, while section 3 provides and discusses the findings of this research, the implications of it, and elicits recommendations. Section 4 concludes this paper.

\subsection{Profiling Absentee Landholders}

The need for an improved understanding of the diversity of rural landholders is increasingly being recognized (Emtage and Herbohn, 2012). Hence, it is crucial to first clearly define the term "absentee landholders" and understand the characteristics of this group, as absentee landholders are not a "homogenous group" (Petrzelka and Armstrong, 2015). For this paper, we follow the definition of absentee landholders presented by Morrison et al. (2015): as people who own or hold land but live remotely from it, often (but not always) holding rural land for reasons of amenity, recreation or conservation rather than profit. 
In the geographic context of this paper (i.e. a rural area of south-eastern Australia within a few hours' drive of a major city), absentee landholdership is primarily driven by amenity and recreation objectives rather than agricultural productivity, with many absentee landholders residing in urban areas. These drivers arise from prior research of Holmes (2006); Meadows et al. (2014); and Ikutegbe, Gill and Klepeis (2015). Of particular relevance is the research of Ikutegbe et al., conducted with absentee landholders in a Local Government Area within the same state (NSW) of this case study; they found that $84.8 \%$ of respondents used their land for rural retreat or recreation, and conservation of native plants and animals, with only $15 \%$ reported to be using their land for the primary purpose of income generation.

Due to absentee landholders not residing on their rural property and not using their land for production purposes, they are likely to be less financially dependent upon the land than resident landholders (Petrzelka, 2013). These characteristics could also explain lower levels of engagement with their land in the form of active management, decision-making and upkeep/maintenance. Additionally, a study from the Noosa Hinterland region of Queensland, Australia, found that most "lifestyle" landholders, of which absentee landholders are a subset, were "former urban dwellers with minimal to no practical natural resource management knowledge and experience" (Meadows et al., 2014). Aside from a lack of knowledge and experience, other factors for low land management engagement amongst absentee landowners include lack of time spent on their properties and a belief that their properties are not suitable for management (Kendra and Hull, 2005). An inability to be present at critical management times (e.g. to implement weed control at critical weed lifestyle stages) can also be a contributing factor (Bond et al., 2017).

\subsection{Implications of amenity-based land uses for rural communities}

Amenity migration is described as the movement of people, mostly affluent and residing in suburban or urban areas, to rural areas for specific lifestyle amenities (Abrams et. al., 2012). This "rural restructuring", as Holmes and Argent (2016) observe in their paper, results in a shift from traditional land uses, social arrangements and economic activities to landscapes related to "post-productivist" or "multifunctional"; making it more evident that the motivations for owning land are changing. There is now a shift from owning land for agricultural production reasons to natural or cultural amenities (Sorice et al., 2014). 
While absentee landholders do not fully migrate to the region in which they have purchased land, they may still contribute to a shift from productivist to amenity values in the region. On top of socio-ecological transformations to the rural landscape (Abrams et al., 2012), these changes result in significant restructuring of the composition and socioeconomic dynamics of rural communities. Consequently, changes in the social structure of rural communities and shift in ownership result in landscapes being fragmented by the increasingly wide-ranging sets of values, beliefs, motivations, and economic circumstances of owners associated with amenity migration (Gosnell et al., 2006). This also presents challenges to natural resource management practitioners, who are striving to implement better resource management strategies across property boundaries. Furthermore, these amenity migrations produce environmental impacts, due to the "social and environmental relations that inform land use and land management being recast" by the values and activities of these new landholders (Ikutegbe, Gill and Klepeis, 2015).

The shift towards increased amenity land use is also evident in many parts of south-eastern Australia, such as the Corangamite region of Victoria, where prior research (Mendham and Curtis 2010) shows that rural areas formerly dominated by production values are changing into more heterogeneous landscapes with a mix of production, protection and conservation. In addition, new owners are less likely to be farmers, more likely to live off property (i.e. be absentee landholders), adopt significantly different land management practices and are motivated more by conservation and recreation rather than production values.

\subsection{Significance of cross-property collaborations for maintaining ecosystem services}

Global environmental targets cannot be sufficiently met with publicly governed protected areas alone (Bond et al., 2017); initiatives underpinned by private landholders through crossproperty collaboration are crucial for landscape-scale conservation initiatives and for ensuring regional ecosystem service delivery, given that ecological boundaries rarely abide by humanimposed boundaries (Meadows et al., 2013).

Environmental management beyond individual property boundaries is required in order to protect and enhance biodiversity across a landscape. However, prior research (mentioned in section 1.1) has shown that absentee landholders lack knowledge and time to manage their land, but value conservation outcomes on their land. Thus, there is an untapped opportunity for private landholders, such as absentees, to make a significant contribution to the 
conservation of biodiversity, along with the preservation of other ecosystem services, by participating in conservation-related collaborations.

\section{Methodology}

\subsection{Study site}

The Central Tablelands of NSW, Australia (see Figure 1 in Maynard et al, this issue), spans around $31,365 \mathrm{~km}^{2}$ and includes the major centres of Bathurst, Orange, Lithgow, Mudgee and Cowra (Figure 2). With a population of more than 150,000 residents, where $7 \%$ are employed in agriculture, fisheries and forestry, the region provides $10 \%$ of NSW's agriculture business, and constitutes more than 3\% of the state's agricultural land (Local Land Services Central Tablelands, n.d.). Amongst the most significant land uses are grazing of sheep and cattle, irrigated farming, broad acre crops and horticultural enterprises (Baumber 2012; Local Land Services Central Tablelands, n.d.).

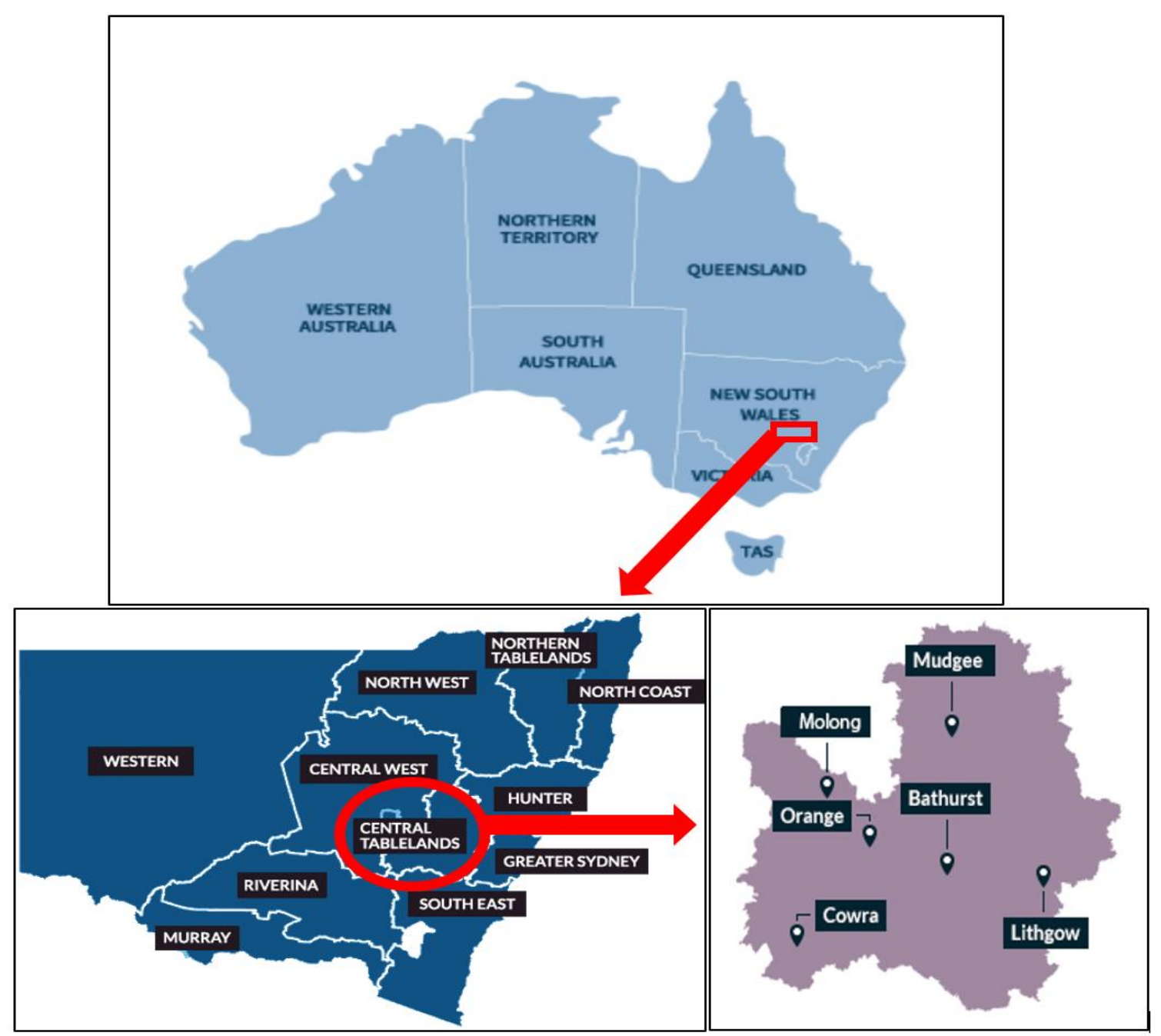

Figure 2. Location of the Central Tablelands within the state of New South Wales (NSW) and Australia. Elaboration: authors with sources from Central Tableland Local Land Services and Open Commons 
Throughout its history, enterprises related to agriculture have largely dominated the economy of the Central Tablelands, although a shift is underway towards a more diverse modern economy that is not only dependent on agriculture, but includes manufacturing, forestry, education, mining and tourism. Ownership of land by "rural lifestylers" has also increased in recent times as part of what Holmes (2006) terms a "multifunctional rural transition" that has affected many areas such as the Central Tablelands that are within a few hours' drive of major cities. Rural lifestylers are typically people who do not depend on their land for income, and may include "pluri-activity" landholders who combine rural amenity with small-scale production such as cattle rearing (Baumber, 2012).

The Central Tablelands Local Land Services (LLS) is one of the key Natural Resource Management (NRM) agencies operating in the case study region. It is responsible for both production and conservation programs, including extension services for agricultural producers, information and advice on conservation-related activities and the provision of funding for activities that align with strategic objectives, such as weed management, feral animal control and bushfire management. Aside from Central Tablelands LLS, the Greater Sydney LLS also has an interest in the provision of NRM information to landholders in the region, since many absentee landholders live in, or near Sydney.

\subsection{Methodological Framework}

\section{Data Collection}

This research adopted an explanatory mixed method approach, consisting of quantitative and qualitative data collection (Creswell et al., 2003 p.565-566); with the former using an online survey, and the latter semi-structured interviews. The collection of quantitative data enabled a broad and general insight on the views of absentee landholders in, or near, Sydney, which was then complemented by the qualitative data that was used for a more in-depth analysis and explanations of the views that absentee landholders held.

Invitations to complete the online survey were sent out to the regions of Sydney and the Central Tablelands through newsletters and Facebook posts by the Central Tablelands LLS, Greater Sydney LLS, and local Landcare groups ${ }^{1}$. This strategy was designed to overcome two challenges: 1) the fact that absentee landholders holding land in the Central Tablelands

\footnotetext{
${ }^{1}$ Local Landcare: A grassroots movement consisting of self-organising volunteers dedicated to the care the land, environment and sustainable management of natural resources. These groups form district, local and regional networks in New South Wales (Landcare 2018).
} 
reside in different parts of the state of NSW, and 2) a unified database of absentee landholders for the whole of NSW does not exist (this is attributed to the highly transient and dynamic nature of absentees). Hence, LLS and Landcare were the only viable channels of contact with absentee landholders of the study region, and newsletters and Facebook posts were the best avenues for contacting absentees.

The online survey containing 23 questions (see Table SI 1, Supplementary Information) was prepared using SurveyMonkey (SurveyMonkey Inc.), and it was opened on August 2017 for three months. Responses from the survey totalled 89, with 64 of the respondents holding land in the Central Tablelands. Noteworthy is that some survey respondents skipped certain questions, therefore the sample size for each figure in the Results section varies.

Following on from the survey, 18 of the respondents participated in further interviews (only absentee landholders with rural property in the Central Tablelands were selected for the interviews). In order to keep the identities of the interview participants confidential, codes were assigned to each participant according to their postal codes (see Table SI 2, Supplementary Information). Group "A" were all from various postcodes, while "B" were from postcodes 2795 and "C" were from 2850. The survey respondents were selected proportionately from these three groups for interviews to avoid an oversaturation of information from landholders of the same area of the case study region. In addition to location, interview participants were also selected based on whether they manage their land on their own, whether they use their land for recreation or for income generation, and years of ownership (see Table SI 2, Supplementary Information). Selection was also limited by availability of the participant (and some did not respond to the invitation for interview).

These interviews were conducted a month and a half after the release of the survey, and were carried out until the end of 2017. These interviews were conducted in-person or over the phone, and recorded with the written and verbal consent of the participant. Interview questions were prepared in advanced, and all 14 questions, established during pre-testing, were used for every interview. 


\section{$\underline{\text { Data Analysis }}$}

All interviewees owned a single property and managed their land on their own. Furthermore, of the 18 participants, 16 owned their land for the purpose of recreation, with the remaining two owning it for investment or income generation. These characteristics (i.e. single property ownership, recreational purpose) were also dominant amongst the broader group of survey respondents. The length of ownership of their property amongst these participants varied, with seven having owned their property for less than 5 years, six having owned it for 6 to 20 years and five having owned it for more than 20 years.

Responses from the semi-structured interviews were coded and analysed using QSR International's NVivo 11 software to identify themes and categories, and to recognize commonalities and differences amongst these themes. Blair (2015) states that "there is no clear-cut 'best' option but that the data coding techniques needed to be reflexively-aligned to meet the specific needs of the project". Hence, this research applied a thematic approach to coding, using a combination of a priori coding (pre-determined) and emergent codes. Additionally, regression analysis was used to analyse relationships among themes, allowing to draw inference about the relationships of interrelated variables. This research established that a p-value with a significance level of less than 0.05 would allow for the rejection of the null hypothesis, while a p-value higher than 0.05 would mean that the null hypothesis cannot be rejected. The null hypothesis for each relationship investigated are presented in the Results section. Scatter plot analysis was also used to observe the relationship between two variables, and common variance. Of specific interest to this research was the variance of the two selected variables (i.e. are they in a random pattern or do they fall along a common line), the nature of the relationship (positive, negative, or none) and whether this relationship was linear.

\section{Results and Discussion}

\subsection{Land use}

Figure 3 summarises results of the online survey with regards to the primary reason survey participants purchased their land. Recreation appears to be the biggest reason for acquiring 


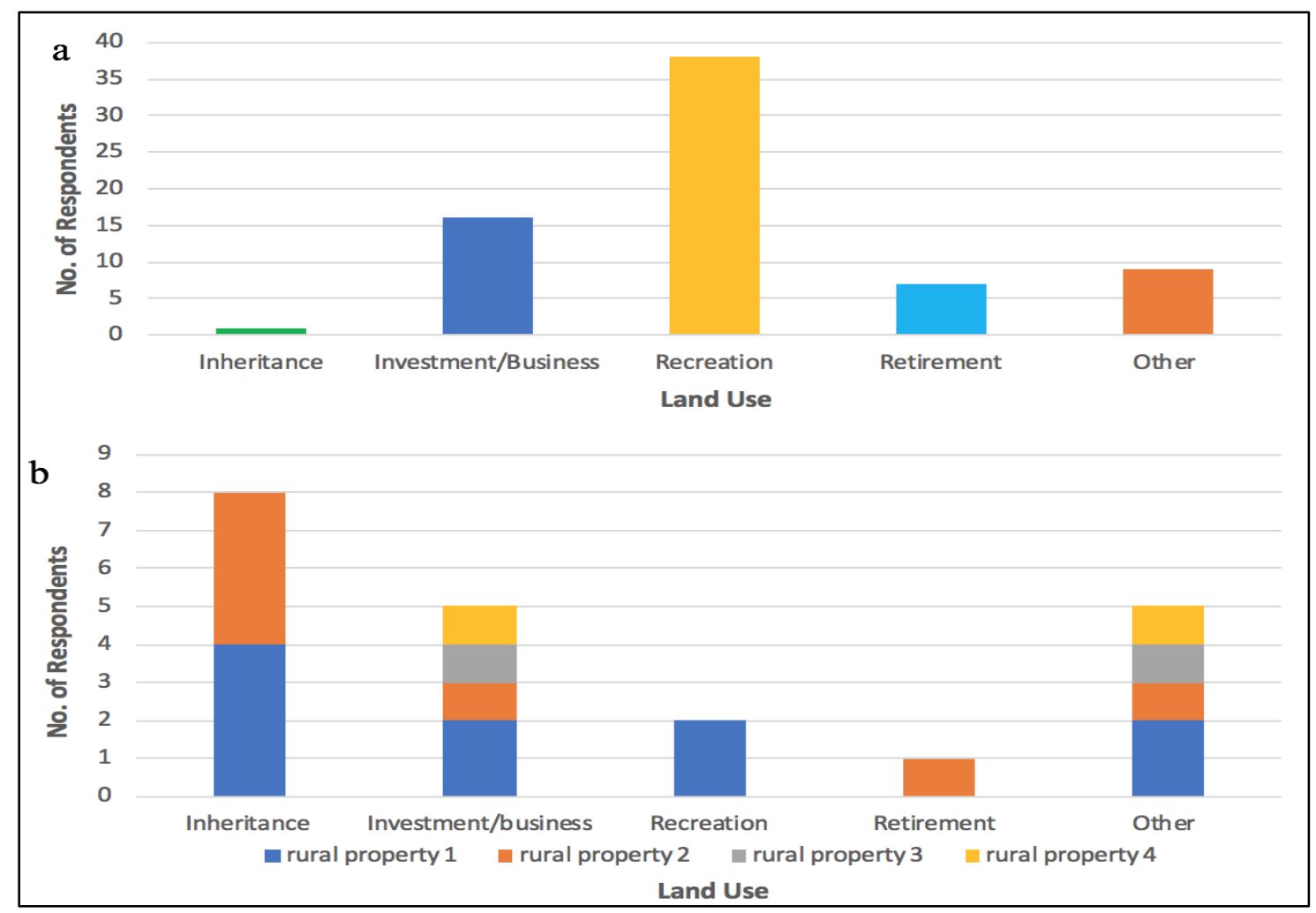

Figure 3. The main reasons behind land acquisition by absentee landholders (a) Respondents with one property (b) Respondents with multiple properties $(\mathbf{n}=\mathbf{8 1})$.

land amongst participants with one property (Figure 3a), with 38 of the 71 respondents $(54 \%)$ selecting this option.

For some, this recreation benefit was linked to amenity and clearly private in nature, including their children's enjoyment of rural life:

So the benefit is that is a place to get away from Sydney for our children too you know, link up with nature, as we did when we were children. A5

Other landholders noted that the recreation or amenity services obtained from the land were linked to supporting ecosystem services involving biodiversity, and the private benefit they obtained was linked to a perceived public benefit involving the conservation of rare or threatened species; for example:

Well it actually gave a lot more than expected. Certainly, in terms of the flora and fauna and also... I suppose the landscape because when we bought it at that stage [we'd] only seen about...a tenth of it, so discovering that remaining $90 \%$ was really exciting and also discovering [the] nearest bird species, which was almost entirely absent from this region...that was really interesting. B4 
Conversely, respondents with multiple properties had different reasons for owning property as compared to single property owners (Figure $3 b$ ), with the main reason for owning property being inheritance followed by investment/business, with recreation only the third most selected reason.

Recreation $^{2}$ is also one of the main uses of land for survey participants with one property (Figure $4 \mathrm{a}$ ), with $51 \%$ of respondents selecting this choice. Lifestyle ${ }^{3}$ is also another main use, with $49 \%$ of participants choosing it. The third biggest land use selected was grazing, at $34 \%$. This is in stark contrast with survey participant who own multiple properties, with grazing and animal cropping, rather than recreation and lifestyle, being the main two uses of the land (Figure 4b).

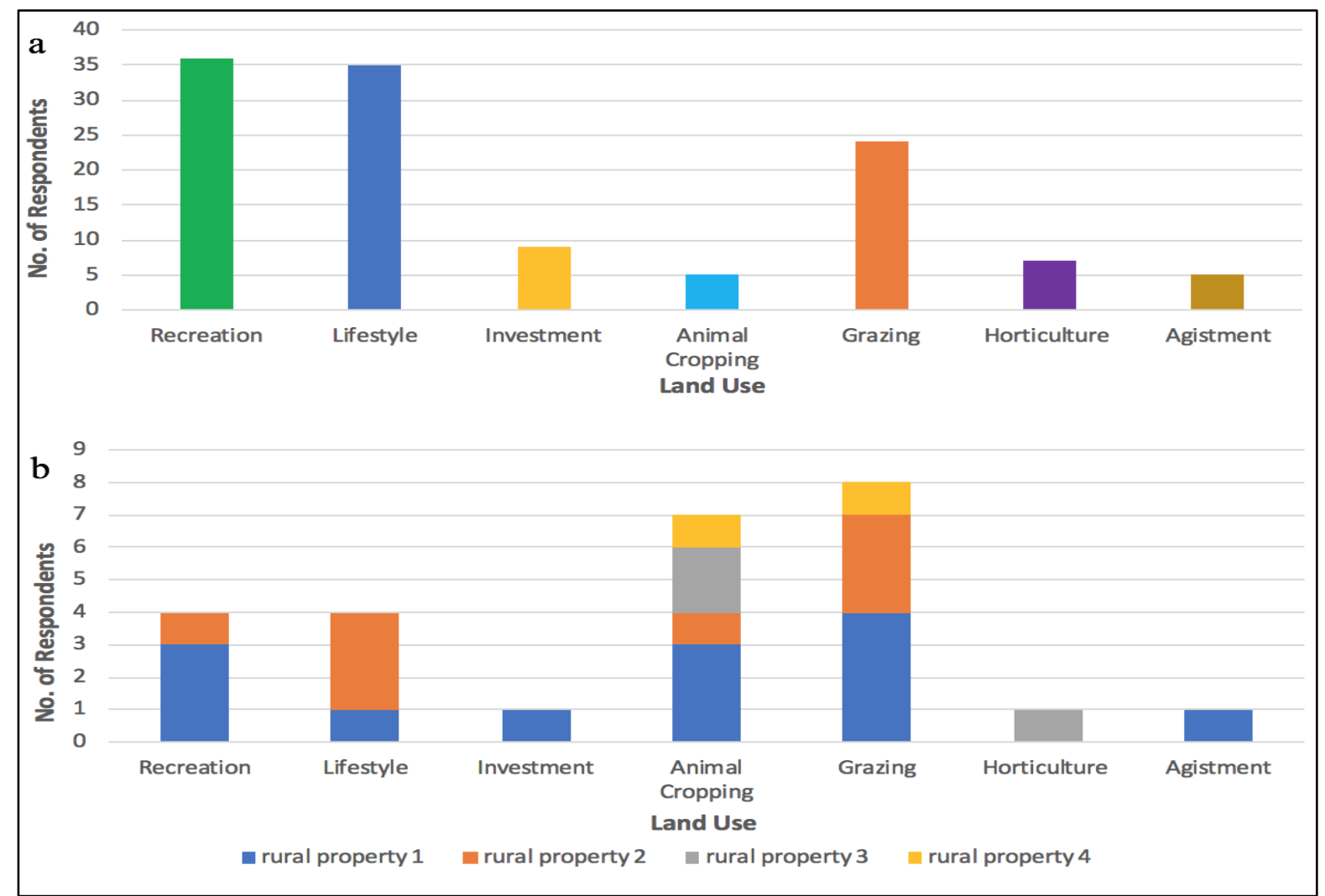

Figure 4. Primary uses of property (a) Respondents with one property (b) Respondents with multiple properties $(\mathbf{n}=\mathbf{8 1})$

Therefore, on the basis of our results, recreation appears to be the biggest driver of land acquisition and primary motivation driving land use by absentee landholders of the case study. Furthermore, absentee landholders participating in this research mostly reside in, or near, the

\footnotetext{
${ }^{2}$ Recreation: defined as hobbies or activities related to private cultural services and not for the purpose of livelihood. This includes using land as a conservation area; wildlife refuge (A5) or as just a horticultural outlet for my interest...challenges of rural life without having to actually make a living out of it (A14).

${ }^{3}$ Lifestyle: covers a wide range of activities, and is defined as (definition supplemented by Pannel and Wilkinson, 2009) peace and quiet, enjoyment, an escape out of Sydney suburban life, into the countryside (C10) or even an education ...for the children, in the broader sense, to understand about nature (C2).
} 
urban areas of Sydney (Figure SI 10 Supplementary Information), with 67\% of those who were interviewed seeing income generation from their land as of low importance (those who score 0 or 1 on "importance of income generation" score in Table 1). Hence, the profile generated from the research results indicates that absentee landholders mostly live in urban areas and are less financially dependent on their land; further validating Petrzelka's (2013) observations on the characteristics of absentee landholders and concurs with the research by Ikutegbe, Gill and Klepeis (2015) research on the South Coast NSW, Australia, which found that only $15 \%$ of absentee landholders used their land for the primary purpose of income generation.

This research also explored whether a correlation existed between the length of ownership and the reasons for buying a property (i.e. whether most owners who have owned their property for 10 years or less bought it for recreational purposes). Research in the early 2000s in Corangamite Watershed (Mendham and Curtis, 2010) indicated a 40-50\% rural property turnover within a decade, with this level predicted to be higher in places with high amenitydriven migration (Section 1.2). We investigated if a similar pattern could be observed in the NSW Central Tablelands. Overall, recreation made up 50\% of the total responses, followed by investment/business, which constituted $23.8 \%$ of total responses (Figure SI 1, Supplementary Information). A closer examination shows that $55 \%$ of survey participants selected recreation as their reason for purchasing their property in the past ten years (Figure SI 2, supplementary information). This trend aligns with prior research that found absentee landholders to be more likely to engage in recreational/amenity purposes (Petrzelka 2013) and indicates that amenity values are playing an increasingly important role in shaping the future of the Australian rural landscape. However, the interviews enabled deeper analysis of absentee landholder motivations and highlighted that recreation, amenity and biodiversity conservation are often highly interlinked, with landholders deriving private amenity benefits from the presence of elements of biodiversity that also offer public benefits in the form of regulating and supporting services (e.g. native vegetation, birds).

\subsection{Land management}

Most survey participants manage land on their own, regardless of the number of properties (Figure SI 3, supplementary information) with $82 \%$ of single property owners managing their property on their own. A similar pattern was found with owners of multiple properties, with more than $75 \%$ of respondents managing the land on their own for all properties. Respondents 
who do not manage their property on their own cited land/farm managers, contractors, tenants and neighbours as people who help with the management of their land.

While data from the interviews reinforced the survey results showing that absentee landholders were active in managing their land on their own, it also showed that absentee landholders do engage the help of others in managing their land, albeit on a short term or temporary basis:

I've managed it myself. I have called in the odd person to do the job because I've got the equipment to do it, so I've had people give help with things and I've had some solar, water pumps put in and things like that. A10

I manage on my own and if I need to have something fertilized, or once I tried to call people in to kill weeds with chemicals. A11

Interviewees were also asked about the importance of both land-based income generation and conservation to them. Data from this question was then quantified and assigned a score using a nominal scale (Table 1). Most interviewees did not place much importance on their land as a source of income generation; with none rating this issue highly (corresponding to the land being a primary or major source of income). Two-thirds of the participants had a score of 0 (no income at all from the land) or 1 (minor income source) (Table 1).

Table 1. Frequencies of each rating for Importance of Income Generation and Importance of Conservation

\begin{tabular}{|l|l|l|l|l|}
\hline & \multicolumn{2}{|l|}{ Ratings } \\
\hline Categories & $\mathbf{3}$ (High) & $\mathbf{2}$ (Moderate) & $\mathbf{1}($ Low) & 0 (Not at all) \\
\hline Income Generation & 0 & 6 & 4 & 8 \\
\hline Conservation & 9 & 4 & 5 & 0 \\
\hline
\end{tabular}

We argue that one reason for the low priority placed on using their property for income generation might rely on the fact that most participants had jobs in urban areas and were not reliant on the rural property for their livelihood:

I'm an executive with the Australian government, so I'm not seeking [income], but we do generate some income from the stays, rental farm stay rental, and we are seeking to generate income from the sheep and from the alpaca wool, [but] it's hardly what [you'd] call a living, it's more of a recreation with some possible income return. C1 
In contrast to income generation, the importance placed on conservation was high amongst the interviewed participants: those who expressed that conservation is important, and have taken steps to maintain and promote conservation. Half of the participants were assigned a score of 3 , with $72 \%$ having a score of 2 or higher (Table 1). Reasons behind this scoring could be attributed to the linkages between recreational/amenity services and conservation, with several interviewees highlighting the importance of native vegetation and animals to their enjoyment of their property:

We're also using it as a conservation area. Wildlife refuge. Because I spend time down there doing things like birdwatching. A5

Well it is, and so the block we purchased only had one tree on it when we purchased it in 2003, and we've planted well over 100 trees, and so all the shade we have on this property has been, is from trees that we've planted. So we are avid tree planters...C1

\subsection{Knowledge and experience in land management practices}

In terms of knowledge and experience with regards to land management practices, most survey participants self-rated their knowledge and experience as moderate in all 5 aspects that were asked (Figure 5). The mode and median yielded a score of 3 for all 5 aspects concerning land management practices, while the weighted average ranged from 3.18 to 3.40 . However, it is worth noting that absentee landholders with the least amount of knowledge may not have been reached through the survey due to their lack of connections with existing social networks.

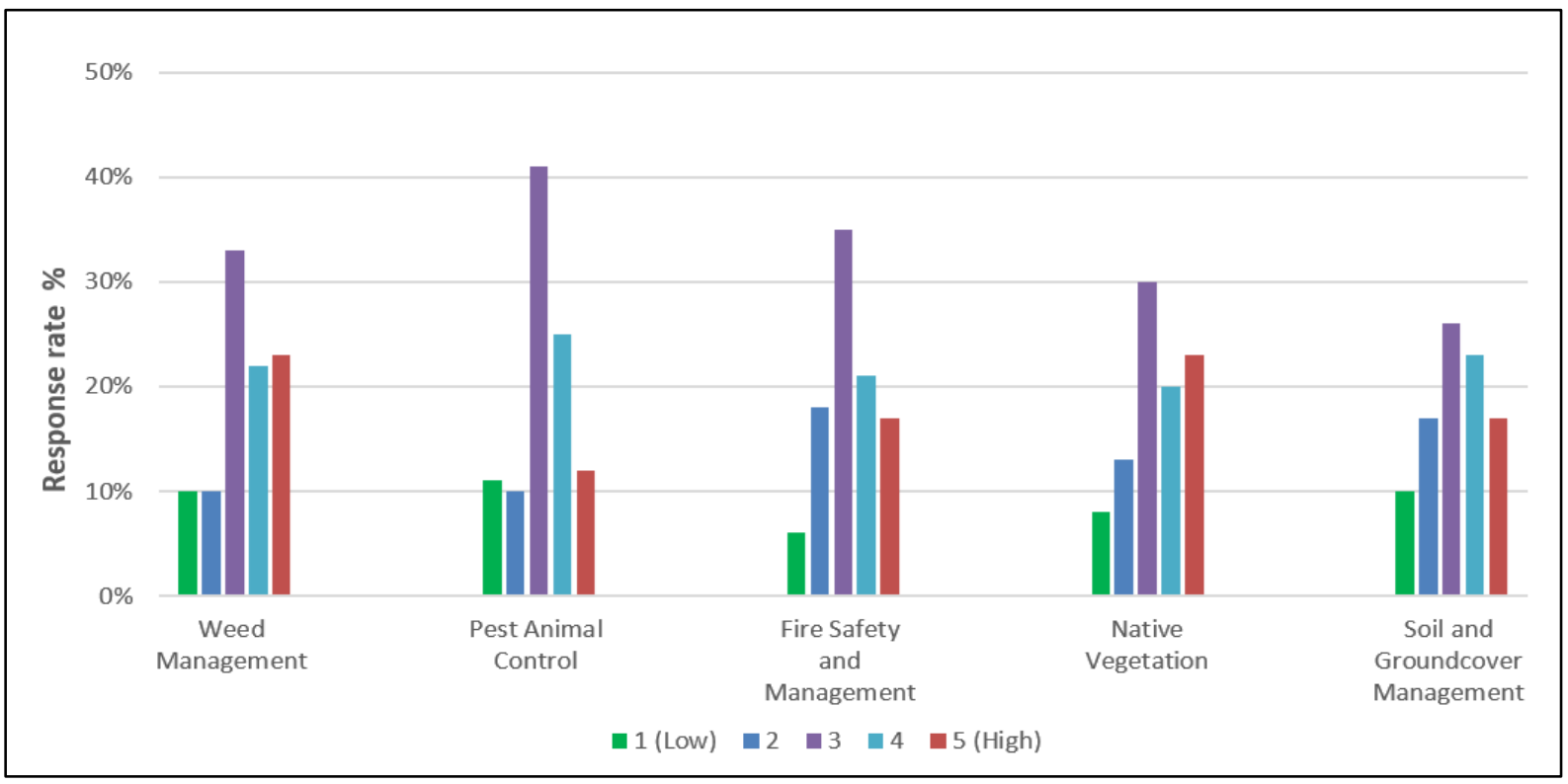

Figure 5. Respondents rating their knowledge and experience of the following land management practices $(\mathbf{n}=\mathbf{8 0})$ 
While self-rated levels of knowledge and experience were almost uniform, the methods used to acquire knowledge varied, as exemplified in the interview responses related to sources of knowledge acquisition. Responses ranged from being raised with a rural background, through education, or from their profession:

Yeah I grew up on a farm when I was young till I was 7, that's a farm out in Cootamundra. Then moved to Queensland when Dad died, I became a shearer when I was 15 , left school and became a shearer. And I lived on farms till I was 24. Then moved to Sydney and did a degree in outdoor education and wilderness management, so learned land management through that degree. C8

I studied agriculture science at Sydney University, and as part of that course, I had to spend 26 weeks work on a farm, doing farm work, so I have previous experience. Even before I went to university, I had a lot of previous knowledge in some aspects of farm work because it was mainly because my grandfather's place was an orchard... In addition to that I've also worked professionally as an ecologist for a long time... and been involved in management planning for bushland reserves so I've got a level of expertise managing bushlands and managing weeds. A5

\subsection{Factors related to levels of knowledge and experience}

The survey data was used to explore two factors that may be correlated to levels of knowledge and experience with land management practices: length of ownership and frequency of property visitation.

Knowledge and experience in land management practices (Y-axis) was measured by adding up each participant's own rating on each of the 5 aspects of land management practice (shown in Table 2). Since each aspect was rated on a scale of 1 to 5 (1 being lowest amount of knowledge and 5 being the highest amount), the scores of each participant were added up using the formula: Level of Knowledge and Experience $=\Sigma \mathrm{A}_{1} \mathrm{X}_{1}+\mathrm{A}_{2} \mathrm{X}_{2}+\mathrm{A}_{3} \mathrm{X}_{3}+\mathrm{A}_{4} \mathrm{X}_{4}+$ $\mathrm{A}_{5} \mathrm{X}_{5}$. 
Table 2. The five aspects of land management practices and scores (1 being the lowest and 5 being highest)

\begin{tabular}{|l|r|}
\hline Aspect & Score $\left(\mathbf{X}_{\mathbf{n}}\right)$ \\
\hline Weed Management $\left(\mathrm{A}_{1}\right)$ & 1 to $5\left(\mathrm{X}_{1}\right)$ \\
\hline Pest Animal Control $\left(\mathrm{A}_{2}\right)$ & 1 to $5\left(\mathrm{X}_{2}\right)$ \\
\hline Fire Safety and Management $\left(\mathrm{A}_{3}\right)$ & 1 to $5\left(\mathrm{X}_{3}\right)$ \\
\hline Native Vegetation $\left(\mathrm{A}_{4}\right)$ & 1 to $5\left(\mathrm{X}_{4}\right)$ \\
\hline Soil and Groundcover Management $\left(\mathrm{A}_{5}\right)$ & 1 to $5\left(\mathrm{X}_{5}\right)$ \\
\hline
\end{tabular}

Length of ownership was measured in years, while frequency of visits was categorised as weekly, every two weeks, monthly or every 2-3 months. Out of the 66 respondents with one property, 56 of them (85\%) visited their property at least once a month, with $23 \%$ of them visiting it every week (Figure SI 4, supplementary information). The remaining respondents $(15 \%)$ visited their property every $2-3$ months.

The plotting of level of knowledge and experience against length of ownership (Figure SI 5a, supplementary information) shows no clear relationship. None of the scatter points fall tightly in a common line; hence it appears that length of ownership might bear no correlation with the level of knowledge and experience. This was confirmed by a regression analysis, which yielded a p-value of 0.66 , indicating that the null hypothesis cannot be rejected (Table 3 ).

Table 3. The null and alternative hypotheses of the correlations explored

\begin{tabular}{|l|l|l|}
\hline & $\begin{array}{l}\text { Length of ownership vs. Levels of } \\
\text { knowledge and experience }\end{array}$ & $\begin{array}{l}\text { Frequency of Visits to property vs. } \\
\text { Levels of Knowledge and Experience }\end{array}$ \\
\hline $\begin{array}{l}\text { Null } \\
\text { hypothesis }\end{array}$ & $\begin{array}{l}\text { The length of ownership has no } \\
\text { correlation on an absentee } \\
\text { landholder's level of knowledge } \\
\text { and experience. }\end{array}$ & $\begin{array}{l}\text { The frequency of visits has no correlation } \\
\text { on an absentee landholder's level of } \\
\text { knowledge and experience in land } \\
\text { management practices. }\end{array}$ \\
\hline $\begin{array}{l}\text { Alternative } \\
\text { hypothesis }\end{array}$ & $\begin{array}{l}\text { The longer an owner has the } \\
\text { property for, the more knowledge } \\
\text { and experience they should have } \\
\text { regarding land management } \\
\text { practices. }\end{array}$ & $\begin{array}{l}\text { The more frequent an absentee landholder } \\
\text { visits their land, the more knowledge and } \\
\text { experience they have. }\end{array}$ \\
\hline
\end{tabular}

Frequency of visitation also showed no correlation with levels of knowledge and experience (Figure SI 5b). Regression analysis conducted on the correlation between frequency of visit and levels of knowledge and experience yielded a p-value of 0.404; meaning that the null hypothesis cannot be rejected. This was in contrast to what we postulated: that frequency of visits may have a positive correlation with the level of knowledge amongst absentee 
landholders as compared to length of ownership, with the rationale being that using length of ownership might be more relevant to farmers or permanent residents of their land, since they live on the land, are more involved in the upkeep of their land and have a higher dependence on the land for agricultural productivity. On the other hand, frequency of visits might be more relevant to absentee landholders, given that those who visit their property more frequently are more involved with their lands and hence have better experience and higher knowledge than those paying less frequent visits. However, this could be specific to absentee properties which are in close proximity (within a few hours drive) to their main place of residence. Therefore, how frequency of visitation and proximity to main residence are related could be another potential area of future research.

\subsection{Connection to local community}

This research examined the strength of connection that absentee landholders had with their local community, as well as with their neighbours. Connectedness to the local community was determined through the online survey using 6 factors (Figure 6). Relationship with their neighbours was the most frequently cited factor contributing to the survey participant's connection to their community (74\%). This was followed by attending local community events $(53 \%)$ and attending workshops and seminars (40\%).

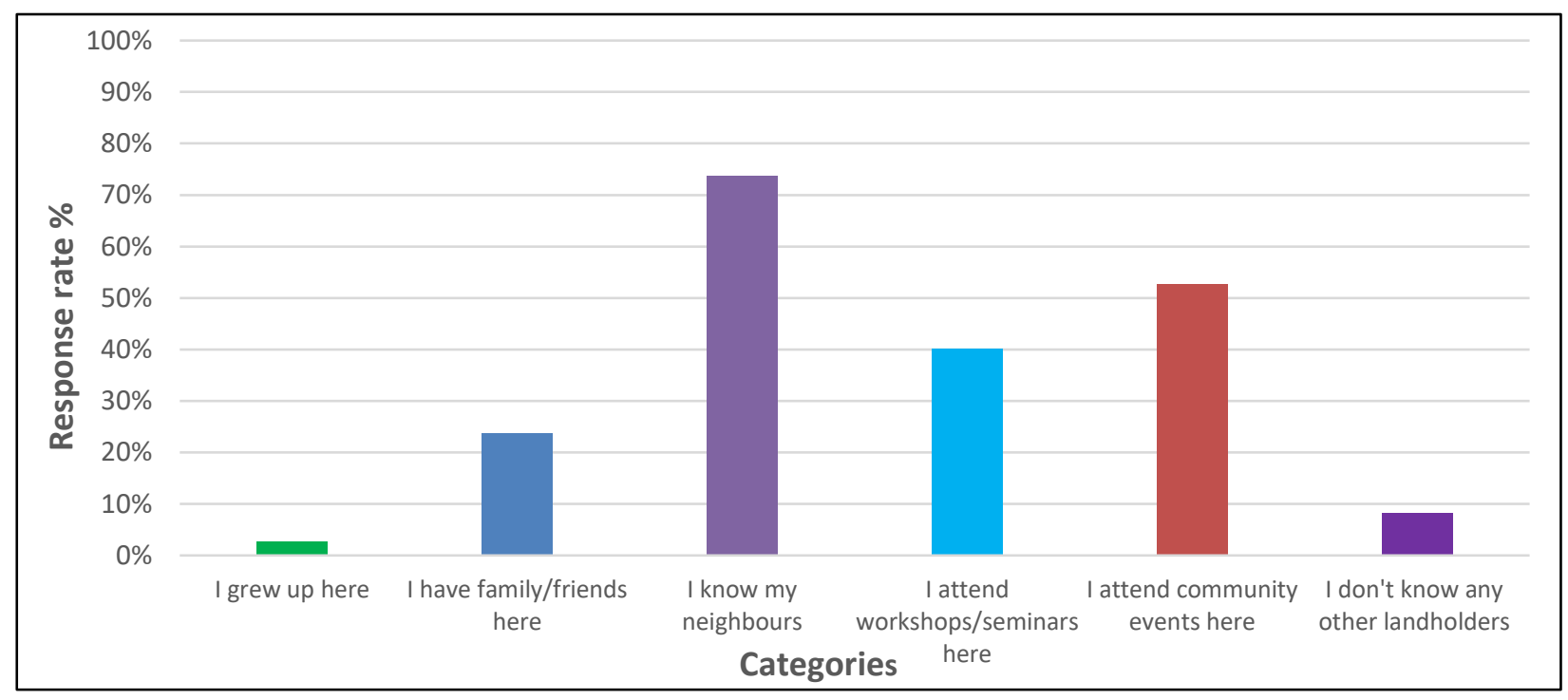

Figure 6. The connectedness of absentee landholders to their local community $(n=72)$

Some survey participants felt that their connection with their local community was weak. Several reasons were cited, including moving to the community just recently, not actively seeking to engage with their neighbours unless needed, or different aims/purposes for their property as compared to their neighbours. This was true for the participants interviewed; some 
attributed the lack of connectedness to the shifts in ownership around them, to their differing interests, or both:

Because it's a mining area, and so there's people who have moved in and moved out, so we've got a number of new neighbours around. $\mathbf{C 1}$

You know I mean that's one of the problems in the valleys... it's got rather different groups of people with different interests and the people who have to make a living... A10

Some interviewees expressed that they would never be able to connect with their local community due to them being absentee landowners. Distance of their properties to the town centres was another factor contributing to this feeling of disconnection:

As an absentee you're never really considered to be a local no matter how long you're there... You're not around all the time. And the other thing is that our house is well over a kilometre and a half off the road and it's a very bad track so typically we get out there, we get to the house and don't sort of go around visiting neighbours...A15

A second aspect of connectedness examined was the strength of relationship that survey participants had with their neighbours. Figure SI 6 shows that most participants self-rating the strength of their relationships with their neighbours at 3 or 4 (out of 5), with a weighted average of 3.6.

That most participants rated their knowledge of neighbours as either a 3 or 4 could reside on the fact that depth of relationship/knowledge amongst neighbours varies, or that neighbours with whom they had a strong bond with had moved away. However, most interview participants expressed strong relationships with neighbours that they do know, with this bond not only fostered through information-sharing but certain land management arrangements as well:

We've got some weeds...if the neighbours [have] been over...[he] comes to my place every now and then, and if he knows there's a weed there or something he'll draw attention to [it] if I haven't noticed it. In terms of, we've got problems with dogs occasionally, or foxes and so on, and he'll do some work to chase off those things. We've obviously collaborated in terms of if there's problems with fences or sheep get out, that sort of thing...It's just whenever I have 
maybe an issue, I give him a ring and we discuss it.

C3

\subsection{Investigating factors related to connectedness to community}

This research sought to understand factors that might have a correlation with an absentee landholder's connectedness to their community, and in turn how connectedness could be correlated to their willingness to collaborate. To this end responses of survey respondents regarding connectedness to their community were quantified in a nominal scale, with scores between 0 to 3 (with 0 being the lowest and 3 being the highest) assigned to the six possible statements elucidating "connectedness to the community" (Table 4). If a survey respondent selected multiple statements, the scores for each statement were added together.

Table 4. Categories for Connectedness to community and the assigned scores

\begin{tabular}{|l|c|}
\hline Qualitative Statement & Assigned score \\
\hline I grew up here & 3 \\
\hline Friends and family here & 3 \\
\hline I know my neighbours & 2 \\
\hline I attend workshops/seminars here & 1 \\
\hline I attend local community events here & 1 \\
\hline I don't know any other local landholder here & 0 \\
\hline
\end{tabular}

It was hypothesized that the longer an absentee landholder had owned a property, the higher their connection to community score would be. Figure SI 7a (supplementary information) plots length of ownership (in years) against rating assigned to connectedness to community. It shows that the length of ownership has no effect on the connectedness to their community, with a large variance expressed in this correlation. A complementary regression analysis provides further proof of this; yielding a p-value of 0.091 , which means that the null hypothesis in Table 5 cannot be rejected.

Frequency of visits to property was also analysed to explore whether it may be correlated with connectedness to community (Figure SI 7b, supplementary information). The graph illustrates that connectedness to community is variable (with the regression line being negative), regardless of how frequent absentee landholders visit their property. A regression analysis conducted to further test this yielded a p-value of 0.418 , indicating that there is no evidence that an absentee landholder's frequency of visits to their property is associated with their feelings of connectedness to their community. 
Table 5. The null and alternative hypotheses of the correlations explored

\begin{tabular}{|l|l|l|}
\hline & $\begin{array}{l}\text { Length of ownership vs. } \\
\text { Connectedness to community }\end{array}$ & $\begin{array}{l}\text { Frequency of Visits to property vs. } \\
\text { Connectedness to community }\end{array}$ \\
\hline $\begin{array}{l}\text { Null } \\
\text { hypothesis }\end{array}$ & $\begin{array}{l}\text { An absentee landholder's length of } \\
\text { ownership of their property has no } \\
\text { correlation with an absentee } \\
\text { landholder's connectedness to their } \\
\text { community. }\end{array}$ & $\begin{array}{l}\text { An absentee landholder's frequency of } \\
\text { visit to their land has no correlation with } \\
\text { the connectedness to their community. }\end{array}$ \\
\hline $\begin{array}{l}\text { Alternative } \\
\text { hypothesis }\end{array}$ & $\begin{array}{l}\text { The length of ownership would have } \\
\text { a correlation with the connectedness } \\
\text { to their community. }\end{array}$ & $\begin{array}{l}\text { The more frequent an absentee landholder } \\
\text { visits their land, the more connected they } \\
\text { would be to their community. }\end{array}$ \\
\hline
\end{tabular}

These results are somehow unexpected given the presupposition that the longer a landholder owns land, or the more often he/she visits it, the more connected they would feel with the local community. However, our interviews with absentee landholders could provide an insight into this. As mentioned above, distance of the rural property to the road and the status of "absentee landholder" could play a role, because as an absentee, you're never really considered to be local no matter how long you're there, you're not around all the time (A15) and because absentee landholders are not a $7^{\text {th }}$ generation, they'll always be an outsider (B2). Hence, these factors could be evaluated in future research as to the significance they have to an absentee landholder's connectedness to the local community, and other possible factors affecting social cohesion.

\subsection{Absentee landholder's interest in collaboration}

In terms of cross-property collaboration, most absentee landholders were interested in the maintenance of supporting and regulating services; with activities such as weed management and pest animal control being the dominant choices at $89 \%$ and $88 \%$, respectively (Figure SI 9 Supplementary Information). This was followed by revegetation and management of riparian zones, both selected by $60 \%$ of the participants. Interest in collaborations for activities such as eco-tourism, branding and marketing of produce, and collective purchase and hire of goods and services were low; less than $30 \%$ of respondents selected collective purchase and hire of goods and services, and selection for branding and marketing of produce and ecotourism were less than $20 \%$. It appears most participants were more interested in conservationrelated collaborations (92\%) rather than production-related collaborations (7\%) (Figure 7). 


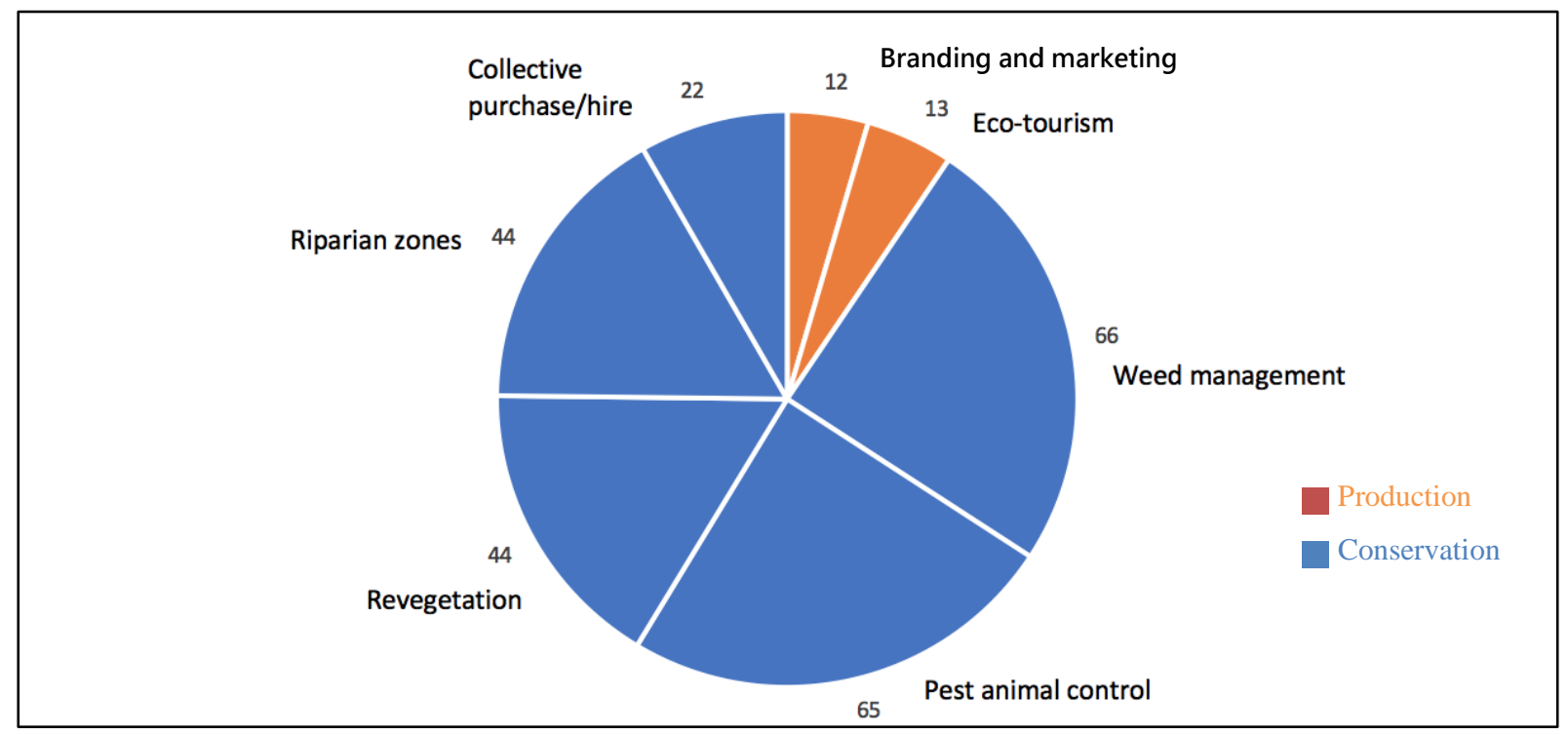

Figure 7. Production collaborations vs Conservation collaborations $(n=74)$

One reason absentee landholders lacked interest in collaborations related to productivity and income generation could be attributed to the fact that most use their land for recreational purposes, and these recreational activities tend to be conservation-related, such as planting trees, revegetating natural bush, and therefore increasing biodiversity.

Results from interviewed absentee landholders also provided a better insight into reasons for collaboration, with one-third of participants expressing that they would like to see a stronger collective effort in order to address some of the problems related to maintenance of services that they face on their land. This is reflected in the quotes below.

I mean in the first year we were there, we spent a lot of time and energy on trying to eradicate the blackberry on our property. Well the neighbour, didn't...so you know what happened...I would have thought that it would be great if there was some sort of collaborative, not control, but administration of how they would control, rather than each farmer doing his own little bit... I felt it wasn't a group effort and it's nobody's fault, I would think that should be organized at a higher level. C10

Knowledge sharing was another reason cited by several participants for collaboration and helping each other:

I mean it's really useful to be able to tap into that local knowledge, so having contact with people who lived in that area for you know maybe 10, 20, 30 years they have a really vital and specialized knowledge about what...Rather than just starting from scratch. No point 
making the same mistakes they might have made on the way to making the right decision. B4

Equipment sharing was another reason cited for collaboration, as absentee landholders saw the value and cost effectiveness in equipment sharing:

I also think in terms of collaborating with tools, well as an absentee landholder...like now we're discussing buying a mechanical auger to help us with this big hole. Now I find it stupid that everybody owns one of those things, when it could be something that you could all pay for in a maintenance point of view and share it in the neighbourhood... So that you know you have a body corporate that maintains them and you pass from one to another and [have] different responsibilities... a collaboration between absentee landholders; that could be cost effective. $\mathbf{C 1 0}$

With this in mind, policymakers interested in enhancing the delivery of public-benefit ecosystem services from private land in regions affected by increasing absentee landholdership and amenity land uses may need to create incentives for collaboration, including compensatory measures for neighbouring landholders to invest time, knowledge and other resources into these collaborations. It is also worth noting that a gap exists in empirical results concerning actual collaborations that could be addressed in future research, in order to better gauge absentee landholder's interest and the success of such collaborations.

\subsection{Investigating the correlation between community connectedness and willingness to collaborate}

The interview data was also used to test the hypothesis that the degree of connection an absentee landholder felt with their respective local communities will be correlated with their willingness to collaborate with their community and neighbours (Table 6). Respondent's willingness to collaborate was scored based on the criteria established in Table SI 3 (supplementary information), while their connectedness was calculated from Table 4. In Figure SI 8 (supplementary information), interview participants scoring a 2 for willingness to collaborate have a huge variance in their scores for connectedness to their community. This is similar with participants having a rating of 1 and below, with their scores for connectedness to community ranging widely from 0 to 6 . However, a weak pattern emerges with people having the highest willingness to collaborate; all of them scored 4 and above for connectedness. As a result, we postulated that the more connected absentee landholders were to their community, the more willing they were to collaborate. However, no correlation was 
found, and this was supported by the regression analysis which produced a p-value of 0.12 (proving that the null hypothesis cannot be rejected). We suggest further research on this topic given that while this result may perhaps indicative, it is not statistically supported with an adequate sample size.

Table 6. The null and alternative hypotheses of the correlations explored

\begin{tabular}{|l|l|}
\hline & Willingness to Collaborate vs Connectedness to community \\
\hline $\begin{array}{l}\text { Null } \\
\text { hypothesis }\end{array}$ & $\begin{array}{l}\text { The connectedness to community has no correlation with an absentee } \\
\text { landholder's willingness to collaborate. }\end{array}$ \\
\hline $\begin{array}{l}\text { Alternative } \\
\text { hypothesis }\end{array}$ & $\begin{array}{l}\text { The higher the connectedness an absentee landholder has for their } \\
\text { community, the more willing they are to collaborate. }\end{array}$ \\
\hline
\end{tabular}

\subsection{Implications of findings for cross-property collaborations towards maintaining ecosystem services}

Conservation-related collaborations should be the focus of future cross-property collaborations, as absentee landholders' motivations and reasons for collaborating are primarily related to weeds, pests and biodiversity. This was also evident in their land use; while amenity and recreation were highly important to participants in this study, it was also related to conservation in many cases, particularly conservation of biodiversity. Furthermore, results from this paper concerning landownership changes, along with prior research, suggest that communities are becoming more fragmented with increasingly diverse values and motivations.

Government agencies and other NRM organizations would need to keep the increasing fragmentation of communities in mind, and accommodate for the growing heterogeneity in values by tailoring their outreach programs accordingly; especially since amenity driven migration, and the fragmentation that arises from it, will likely increase in the future. New incentives for collaboration may need to be established as well, including compensatory measures for the costs that neighbouring resident landholders may incur by providing the knowledge and time required for these collaborations. These measures are to ensure that participation in initiatives are enhanced, and the potential results through increased collective efforts are maximized, given that participating in cross-property collaborations is critical if policymakers want absentee-owned land to deliver public ecosystem services, alongside the private cultural services it provides to absentee landholders at present. Without collaboration, 
absentee-held land is less likely to provide public-benefit ecosystem services. Moreover, for absentees who lack the time to visit and the knowledge to manage, collaborations have the potential to make up for these shortcomings.

Initiatives like the Greater Sydney Absentee Landholder Network are creating pathways for increased engagement, but further initiatives to support this are required to enable lateral collaboration with neighbours across properties. Groups that are already enabling collaboration locally, for example Landcare, could be resourced to have an absentee outreach program, and absentees could be strongly encouraged or incentivised (for example, via messages like "avoid fines for having weeds or major fire hazards on your property by joining Landcare today") by local council to join Landcare.

Noteworthy is that most absentee landholders in the Central Tablelands appear to be engaged and have self-reported intermediate levels of knowledge and experience concerning land management practices; meaning outreach efforts by government to inform absentee landholders about cross-property collaborations, and the resources needed to educate them on land management practices through workshops and courses, might not be as extensive as first expected. Additionally, due to the perceived moderate to high levels of knowledge and experience concerning land management practices, more advanced and larger scale collaborations that will further enhance the delivery of public ecosystem services could be proposed in the future.

\section{Conclusion}

As in other parts of Australia, this study found that land acquisition by absentee landholders in the NSW Central Tablelands is being driven by the provision of lifestyle services in the form of recreation and amenity, often intertwined with supporting and regulating services related to the conservation of native vegetation and fauna. It was also found that land-based income generation was a low priority for absentee landholders and that they were relatively engaged with their land given their frequency of visits to their rural property. In addition, neighbours were found to be an important source of connection to the local community for absentee landholders, with other sources of connection including local community events, workshops and seminars. 
Cross-property collaboration emerged as an important factor in the delivery of public-benefit ecosystem services from absentee-held land. Absentee landholders appear more interested in conservation-related collaborations that involve regulating or supporting services that have both private and public benefits (such as management of weeds, pests and biodiversity) than in cultural or provisioning services. By enhancing understanding of the relationships between connectedness, frequency of visits, and reasons behind desire for collaboration, better support and/or incentive measures for localised groups to maintain absentee relations could be developed.

\section{References}

ABRAMS, J.B., GOSNELL, H., GILL, N.J. AND KLEPEIS, P.J., 2012. Re-creating the rural, reconstructing nature: An international literature review of the environmental implications of amenity migration. Conservation and Society, 10(3), pp.270-284.

BAUMBER, A., 2012. Harnessing bioenergy as a driver of revegetation: an analysis of policy options for the New South Wales Central West, Australia (Doctoral Dissertation).

BAUMBER, A., METTERNICHT, G., AMPT, P., CROSS, R. \& BERRY, E. 2018. 'From importing innovations to co-producing them: Transdisciplinary approaches to the development of online land management tools', Technology Innovation Management Review 8(6). http://doi.org/10.22215/timreview/1175

BLAIR, E. 2015. A reflexive exploration of two qualitative data coding techniques. Journal of Methods and Measurement in the Social Sciences, Vol.6, No. 1, 14-29

BOND, A. J., O'CONNOR, P. J. \& CAVAGNARO, T. R. 2018. Who participates in conservation incentive programs? Absentee and group landholders are in the mix. Land Use Policy, 72, 410-419.

BUMAN, T. 2007. Reaching out to absentee landowners. Journal of Soil and Water Conservation, 62, 36A.

CENTRAL WEST INDEPENDENT REVIEW PANEL (2007). Review of Land Use Planning in the Central West: Report to the Minister for Planning, Central West Rural Lands Inquiry, Sydney, 22p.

CRESWELL, J. W., PLANO CLARK, V. L., GUTMANN, M. L. \& HANSON, W. E. 2003. Advanced mixed methods research designs. In A. Tashakkori and C.Teddlie (eds) (2003), Handbook of mixed methods in social and behavioral research (pp. 209-240). Thousand Oaks, CA: SAGE Publications, Inc.

EMTAGE, N. \& HERBOHN, J. 2012a. Assessing rural landholders diversity in the Wet Tropics region of Queensland, Australia in relation to natural resource management programs: A market segmentation approach. Agricultural Systems, 110, 107-118. 
GOSNELL, H., HAGGERTY, J. H. \& TRAVIS, W. R. 2006. Ranchland ownership change in the greater yellowstone ecosystem, 1990-2001: Implications for conservation. Society \& Natural Resources, 19, 743-758.

HOLMES, J. 2006. Impulses towards a multifunctional transition in rural Australia: gaps in the research agenda. Journal of rural studies, 22, 142-160.

HOLMES, J. AND ARGENT, N., 2016. Rural transitions in the Nambucca Valley: Sociodemographic change in a disadvantaged rural locale. Journal of rural studies, 48, pp.129-142.

IKUTEGBE, V., GILL, N. \& KLEPEIS, P. 2015. Same but different: sources of natural resource management advice for lifestyle oriented rural landholders. Journal of Environmental Planning and Management, 58, 1530-1543.

KENDRA, A. AND HULL, R.B., 2005. Motivations and behaviors of new forest owners in Virginia. Forest Science, 51(2), pp.142-154.

LANDCARE NSW 2018, Landcare NSW- Who are we, http://landcarensw.org.au/wp-content/uploads/2018/11/FINAL_Who-is LNSW brochure_WEB.pdf

LOCAL LAND SERVICES, CENTRAL TABLELANDS n.d., Regional Profile, LLS, Central Tablelands http://centraltablelands.lls.nsw.gov.au/our-region/region-profile

MEADOWS, J., HERBOHN, J. \& EMTAGE, N. 2013. Supporting Cooperative Forest Management among Small-Acreage Lifestyle Landowners in Southeast Queensland, Australia. Society \& Natural Resources, 26, 745-761.

MEADOWS, J., EMTAGE, N. \& HERBOHN, J. 2014. Engaging Australian small-scale lifestyle landowners in natural resource management programmes - Perceptions, past experiences and policy implications. Land Use Policy, 36, 618-627.

MENDHAM, E. \& CURTIS, A. 2010. Taking Over the Reins: Trends and Impacts of Changes in Rural Property Ownership. Society \& Natural Resources, 23, 653-668.

MERSON, J., AMPT, P., RAMMELT, C. \& BAUMBER, A. 2011. Bioenergy from Native Agroforestry: An assessment of its potential in the NSW Central Tablelands. Rural Industries Research and Development Corporation, Canberra, RIRDC Publication No. 11/065, 109p.

MILLENNIUM ECOSYSTEM ASSESSMENT 2003. Ecosystems and Human Well-Being: A Framework For Assessment. Island Press, Millennium Ecosystem Assessment (2003)

MORRISON, M., GREIG, J., READ, D. M. Y., WALLER, D. S. \& MCCULLOCH, R. 2015. Communicating information to difficult-to-reach landholders: perspectives of natural resource management communication practitioners. Australasian Journal of Environmental Management, 22, 315-328. 
PANNELL, D. J. \& WILKINSON, R. 2009. Policy mechanism choice for environmental management by non-commercial "lifestyle" rural landholders. Ecological economics, 68, 2679-2687.

PETRZELKA, P. \& ARMSTRONG, A. 2015. Absentee landowners of agricultural land: Influences upon land management decision making and information usage. Journal of Soil and Water Conservation, 70, 303-312.

PETRZELKA, P., MA, Z. \& MALIN, S. 2013. The elephant in the room: Absentee landowner issues in conservation and land management. Land Use Policy, 30, 157166.

REDMON, L.A., CLARY, G.M., CLEERE, J.J., EVERS, G.W., HABY, V.A., LONG, C.R., NELSON, L.R., RANDEL, R.D., ROUQUETTE Jr, M., SMITH, G.R. and THRIFT, T.L., 2004. Pasture and Livestock Management Workshop for Novices: A New Curriculum for a New Clientele. Journal of natural resources and life sciences education, 33, pp.7-10.

RICKENBACH, M., SCHULTE, L. A., KITTREDGE, D. B., LABICH, W. G. \& SHINNEMAN, D. J. 2011. Cross-boundary cooperation: A mechanism for sustaining ecosystem services from private lands. Journal of soil and water conservation, 66, 91A-96A.

SORICE, M. G., KREUTER, U. P., WILCOX, B. P. \& FOX III, W. E. 2014. Changing landowners, changing ecosystem? Land-ownership motivations as drivers of land management practices. Journal of Environmental Management, 133, 144-152.

ULRICH-SCHAD, J. D., BABIN, N., MA, Z. \& PROKOPY, L. S. 2016. Out-of-state, out of mind? Non-operating farmland owners and conservation decision making. Land Use Policy, 54, 602-613. 